\title{
Age-Dependent Fecundity of Podisus nigrispinus (Dallas) (Heteroptera: Pentatomidae) with Sublethal Doses of Gammacyhalothrin
}

\author{
Alexandre Igor Azevedo Pereira ${ }^{1}$, Francisco de Sousa Ramalho ${ }^{1 *}$, Catarina de Medeiros \\ Bandeira ${ }^{1}$, José Bruno Malaquias ${ }^{1}$ and José Cola Zanuncio ${ }^{2}$ \\ ${ }^{1}$ Unidade de Controle Biológico; Embrapa Algodão; C. P.: 174; 58107-720; Campina Grande - PB - Brasil. \\ ${ }^{2}$ Departamento de Biologia Animal; Universidade Federal de Viçosa; Viçosa - MG - Brasil
}

\begin{abstract}
Podisus nigrispinus (Dallas) (Heteroptera: Pentatomidae) was exposed to gammacyhalothrin to study the stimulatory effect of low concentrations of this pyrethroid. The doses studied were 23.4375, 11.7188, 5.8594, 2.9297, 1.4648, 0.7324 mg.litre ${ }^{-1}$ and water, as control. The third, fourth, and fifth instars of P. nigrispinus were shorter with all the doses of this insecticide. The survival and longevity of this predator was highest with the lowest doses. The oviposition period of $\mathrm{P}$. nigrispinus decreased as the doses increased. The lowest pre- and

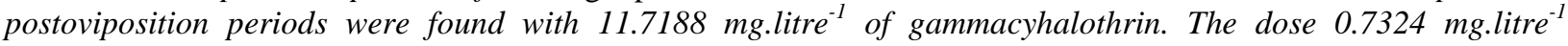
increased the clutch interval. The egg viability was similar between the treatments. The number of eggs per clutch, clutches per female, incubation period, and female body weight were not affected. The hormesis response could be used as a tool for IPM programs, allowing the manipulating parameters of this predator in synergism with this insecticide.
\end{abstract}

Key words: Predator, pyrethroid, stink bug, hormesis, biology

\section{INTRODUCTION}

The cotton leafworm, Alabama argillacea (Hübner) (Lepidoptera: Noctuidae) belongs to the major lepidopteran cotton pest group in Brazil (Ramalho, 1994; Silva et al., 1997) and chemical control is frequently used against this pest.

The insecticides can be used on the cotton crop but the deposited materials of spray programs, even at low doses can affect pests and natural enemies. The effectiveness of sublethal doses and their consequences for the environment are questionable, but adverse effects on biological parameters by low doses of chemicals have been shown (Alford and Holmes, 1986; Perveen, 2000). Positive or stimulatory effects of insecticides on arthropods are attributed to the hormesis phenomenon (Toft and Jensen, 1998) which has been often overlooked. The hormetic response exhibits relationships with low-dose stimulation and high-dose inhibition (Calabrese and Baldwin, 2002).

Pentatomid stink bugs of the genus Podisus are biocontrol agents for several crops (Ruberson et

*Author for correspondence: framalho@pesquisador.cnpq.br 
al., 1994). Podisus nigrispinus is an important regulator of the cotton leafworm in Brazil (Medeiros et al., 2003) and continuous applications of chemical insecticides against this pest can cause undesirable effects, especially on non-target organisms (McCutcheon and DuRant, 1999). These chemicals can have xenobiotic impacts which could also affect the behavior and physiology of natural enemies as a result of the hormetic phenomenon.

The great mobility and susceptibility to low doses of insecticides make predators and parasitoids more susceptible to these chemicals than their prey and host species (Boyd and Boethel, 1998). Attempts have been done to identify, conserve, augment or manipulate populations of beneficial insects (Fitt, 2000). A few studies have been carried out to assess the hormetic effects on natural enemies after pesticide use. This is necessary because the understanding of the hormesis phenomenon on natural enemies is an important tool of Integrated Pest Management (IPM) in the cotton crop. Therefore, the effect of sublethal doses of the pyrethroid gammacyhalothrin was evaluated on nymphs and adults (males and females) of $P$. nigrispinus, a predator of lepidopteran pests on cotton crop. Gammacyhalothrin is a pyrethroid insecticide commonly used against cotton pests in Brazil.

\section{MATERIALS AND METHODS}

\section{Insect rearing}

Podisus nigrispinus nymphs and their prey $M$ Musca domestica L. (Diptera: Muscidae) were obtained from mass rearing facilities of the "Unidade de Controle Biológico (UCB)" at the "Embrapa Algodão" in Campina Grande, in the state of Paraíba, Brazil. All bioassays were conducted with the insects in growth chambers. The rearing conditions were at $26 \pm 1^{\circ} \mathrm{C}$; photoperiod of L:D $12: 12$, and $60 \pm 10 \%$ relative humidity. The parental generation of $P$. nigrispinus was fed on Tenebrio molitor L. (Coleoptera: Tenebrionidae) and $M$. domestica larvae.

\section{Chemicals}

Gammacyhalothrin is the active isomer of lambdacyhalothrin ((S)-a-cyano-3-phenoxybenzyl (Z)- (1R,3R)-3-(2-chloro-3,3,3-trifluoripropenyl)2,2-dimethylcyclo-propanecarboxylate) and its concentrate suspension was supplied by Dow AgroSciences Industrial Ltda, Brazil.

Sublethal Effects on Immature Stages. Egg clutches of $P$. nigrispinus with a total of 1000 eggs used in the bioassays were maintained in 10 Petri dishes $(9.0 \times 1.5 \mathrm{~cm})$ with a moist cotton ball to keep moisture. First instar nymphs of this predator were kept in similar Petri dishes until the next moult. Second instar nymphs of $P$. nigrispinus were isolated in $100 \mathrm{ml}$ plastic cups with a cover. All the cups used had a circular hole in the cover in which a $2.5 \mathrm{ml}$ cylindrical plastic tube was inserted. The opening of these tubes was plugged with cotton to supply water and to keep the moisture in the cups.

Six sublethal concentrations of the insecticide gammacyhalothrin were used, based on results from previous toxicity bioassay. This insecticide was diluted in distilled water to obtain the following doses: 23.4375, 11.7188, 5.8594, 2.9297, 1.4648, and $0.7324 \mathrm{mg}$. litre $^{-1}$. Each second instar nymph of $P$. nigrispinus received a topical application of one microliter $(1 \mu \mathrm{l})$ of each concentration of the insecticide on their thorassic dorsum with a calibrated micro-syringe or $1 \mu$ of distilled water in the control, immediately after their moult in accordance with the treatment.

The development period (monitored until adult emergence) for each instar of $P$. nigrispinus was obtained and measured on a daily basis between moulting. Survival was calculated as the inverse of the nymph mortality with each dose using the data from second to fifth instar as a percentage. The nymphs were observed daily and fed ad libitum with $M$. domestica, receiving water when necessary.

\section{Sublethal Effects on Body Weight, Longevity,} and Reproductive Parameters

Newly-emerged females of $P$. nigrispinus were mated immediately after adult emergence in 250 $\mathrm{ml}$ plastic cups. Female body weight was measured on an analytical balance $( \pm 0.1 \mathrm{mg})$, model "Mettler H31AR". These adults received water in the same way as the nymphs and a total of $15 M$. domestica larvae were supplied daily per $P$. nigrispinus pair. These pairs were placed in growth chambers in which they were fed daily. The following factors were observed: preoviposition, oviposition and postoviposition periods, clutch interval, number of cluthes per 
female, number of eggs per female, number of eggs per clutch and longevity of adult females. The egg clutches were collected daily and kept in Petri dishes with a cotton ball wedded in distilled water to obtain the incubation period and egg viability. The clutches were kept in a growth chamber at $26^{\circ} \mathrm{C}, 60 \pm 10 \%$ of relative humidity and photoperiod of L:D 12:12.

The males which died before their respective females, were replaced immediately. The adult females that died before nine days were not used in the statistical analysis.

\section{Data Analysis}

The data was submitted to ANOVA and the average compared with the Student-NewmanKeul's test $(p=0.05)$. The mortality of $P$. nigrispinus was evaluated by probit analysis (Sas Institute Inc., 2004). The data of the number of eggs per female was divided into five day old groups to obtain the age-dependent fecundity model for this predator. Mean and standard deviations of the number of eggs per female per day were calculated for each age class.

\section{RESULTS AND DISCUSSION}

\section{Sublethal Effects on Development and Survival of the Immature Stages}

The sublethal doses of gammacyhalothrin reduced the duration of third $(\mathrm{F}=3.65, p=0.05)$, fourth $(\mathrm{F}=$ $3.38, p=0.05)$ and fifth instars $(\mathrm{F}=6.72, p=0.05)$. The duration of the second instar of $P$. nigrispinus $(\mathrm{F}=1.91, p>0.05)$ was similar in the doses of gammacyhalothrin and the control (Table 1). The doses of this pyretroid reduced the duration of the fifth instar of $P$. nigrispinus compared to the control; the treatment with the 23.4375 mg.litre ${ }^{-1}$ dose of gammacyhalothrin had the shorter duration in relation to this insect (4.78 days) (Table 1). The predator Supputius cincticeps (Stal) (Heteroptera: Pentatomidae) submitted to sublethal doses of permethrin had a shorter duration of third instar for those which originated females (Zanuncio et al., 2003). The duration of the third and fourth instar of Podisus distinctus (Stal) (Heteroptera: Pentatomidae) was shorter with certain sublethal doses of permethrin (Jusselino Filho, 2002). The spined soldier bug Podisus maculiventris (Say) (Heteroptera: Pentatomidae) had a longer fourth and fifth instar when exposed to sublethal doses of the insect growth regulator teflubenzuron
(Mohaghegh et al., 2000). Olla v-nigrum (Mulsant) (Coleoptera: Coccinellidae) showed a longer larva stage after $24 \mathrm{~h}$ exposed to the residues of Copper Sulphate and Petroleum Oil (Michaud and Grant, 2003).

Hormesis is advantageous to individuals when resources are initially and principally allocated to fix problems caused by immediate damage (Calabrese and Baldwin, 2002). However, an adequate and constant food supply can provide energy for all the physiological processes, even after exposure to a toxic agent in sublethal doses.

The age-specific survival showed that the survival of $P$. nigrispinus continuously decreased with all sublethal doses of gammacyhalothrin (Fig. 1). Survival curves of this predator decreased at a faster rate when exposed to $23.4375 \mathrm{mg}$.litre ${ }^{-1}$ than to $1.4648 \mathrm{mg} \cdot$ litre $^{-1}$ of the pyretroid with the highest difference of survival of these two doses in the age-class of 11-15 days.

The survival of $P$. nigrispinus was directly related to the dose of the gammacyhalothrin. The addition of low levels of carbaryl stimulated the survival of tadpoles of the bullfrog Rana catesbeiana Shaw (Anura: Ranidae) (Boone and Semlitsch, 2003). The lowest survival of $P$. nigrispinus was found in 23.4375 to 11.7188 mg.litre ${ }^{-1}$ of gammacyhalothrin $(28.12$ and $25.51 \%$, respectively). The nymphs of this predator exposed to intermediary doses (5.8594 and 2.9297 mg.litre ${ }^{-1}$ ) showed a higher survival rate than those with the two highest doses; however, the highest survival rates (48.04 and $43.69 \%$, respectively) and those most similar to the control were observed with 1.4648 and 0.7324 mg.litre ${ }^{-1}$ $(50.94 \%)$ (Table 1). Yokoyama and Pritchard (1984) reported that the survival rates of the western big eyed bug, Geocoris pallens Stal (Heteroptera: Lygaeidae) were lower after exposure to the highest sublethal dose of an acaricide. $P$. maculiventris had a high mortality (males: $80 \%$ and females: $75 \%$ ) with the sublethal dose of $8 \mathrm{mg} \cdot$ liter $^{-1}$ (LC10) of diafenthiuron in drinking water (De Cock et al., 1996).

Insecticide residue in cotton may result in higher mortality in the hooded beetle Notoxus monodon Fabricius (Coleoptera: Anthicidae) than in the big eyed bug Geocoris punctipes Say (Heteroptera: Lygaeidae) (McCutcheon and Durant, 1999). The apparent low survival rates of these insects in the treated and untreated plots as well as the differences in the level of susceptibility of specific predators to chemical insecticides are important 
factors. The survival of three coccinelid species was similar to the control after exposure to sublethal doses of a copper sulfate fungicide (Michaud and Grant, 2003) but the number of individuals of $G$. punctipes was reduced in the field by the sublethal effects of the S-1812 (a dihalopropenytoxy benzene insecticide) (Tillman and Mulroney, 2000).

The higher mortality of $P$. nigrispinus nymphs with the highest doses of gammacyhalothrin could be explained by the different cuticular penetration rate in nymphs and adults of $P$. nigrispinus. A fast penetration rate through the nymph cuticle could increase the toxicity of the chemical even at sublethal doses. Although the cuticle of adults is thicker and more rigid than that of nymphs, a reduced penetration rate through their cuticle in adults may explain the differences in toxicity due to insecticides (Yu, 1998; Pereira et al., 2005). The sensitivity of organisms to biological and chemical stressors also differs from one species to another.

Table 1 - Development period (days) and survival (\%) (mean* ${ }^{*}$ standard error) of Podisus nigrispinus (Heteroptera: Pentatomidae) nymphs submitted to topical application of sublethal doses of gammacyhalothrin at $26^{\circ} \mathrm{C}$, relative humidity of $60 \pm 10 \%$, and photoperiod of L:D 12:12.

\begin{tabular}{|c|c|c|c|c|c|c|}
\hline \multirow[t]{2}{*}{$\begin{array}{c}\text { Dose } \\
\left(\text { mg.litre }^{1}\right)\end{array}$} & \multicolumn{4}{|c|}{ Instars (mean \pm standard error) ${ }^{1}$} & \multirow[t]{2}{*}{ Survival $^{1}(\%)$} & \multirow[t]{2}{*}{$\begin{array}{l}\text { Number of } \\
\text { Individuals }\end{array}$} \\
\hline & $2^{\text {nd }}$ & $3^{\text {rd }}$ & $4^{\text {th }}$ & $5^{\text {th }}$ & & \\
\hline 23.4375 & $3.85 \pm 0.21 \mathrm{a}$ & $3.65 \pm 0.47 b$ & $3.56 \pm 0.26 b$ & $4.78 \pm 0.14 \mathrm{c}$ & $28.12 \mathrm{c}$ & 96 \\
\hline 11.7188 & $3.49 \pm 0.28 \mathrm{a}$ & $3.34 \pm 0.35 b$ & $3.53 \pm 0.30 b$ & $5.41 \pm 0.11 b c$ & $25.51 \mathrm{c}$ & 98 \\
\hline 5.8594 & $3.45 \pm 0.18 \mathrm{a}$ & $3.46 \pm 0.34 b$ & $3.84 \pm 0.39 b$ & $5.31 \pm 0.12 b c$ & $32.98 \mathrm{~b}$ & 94 \\
\hline 2.9297 & $3.82 \pm 0.20 \mathrm{a}$ & $3.32 \pm 0.27 b$ & $3.80 \pm 0.45 b$ & $5.69 \pm 0.16 b$ & $36.63 \mathrm{~b}$ & 101 \\
\hline 1.4648 & $3.81 \pm 0.20 \mathrm{a}$ & $3.46 \pm 0.44 b$ & $3.99 \pm 0.50 \mathrm{~b}$ & $5.30 \pm 0.02 b c$ & $48.04 \mathrm{a}$ & 102 \\
\hline 0.7324 & $3.51 \pm 0.06 \mathrm{a}$ & $3.70 \pm 0.47 b$ & $4.04 \pm 0.55 b$ & $5.21 \pm 0.27 \mathrm{bc}$ & $43.69 \mathrm{a}$ & 103 \\
\hline Control & $3.45 \pm 0.15 \mathrm{a}$ & $4.85 \pm 0.18 \mathrm{a}$ & $5.66 \pm 0.22 \mathrm{a}$ & $6.47 \pm 0.37 \mathrm{a}$ & $50.94 \mathrm{a}$ & 106 \\
\hline $\mathrm{F}=$ & $1.91(p>0.05)$ & $3.65(\mathrm{p}=0.05)$ & $3.38(p=0.05)$ & $6.72(p=0.05)$ & $12.72(p=0.05)$ & ----- \\
\hline
\end{tabular}

$*$ Means followed by the same letter within each column are not different according to the Student-Newman-Keul's test $(p=0.05)$.

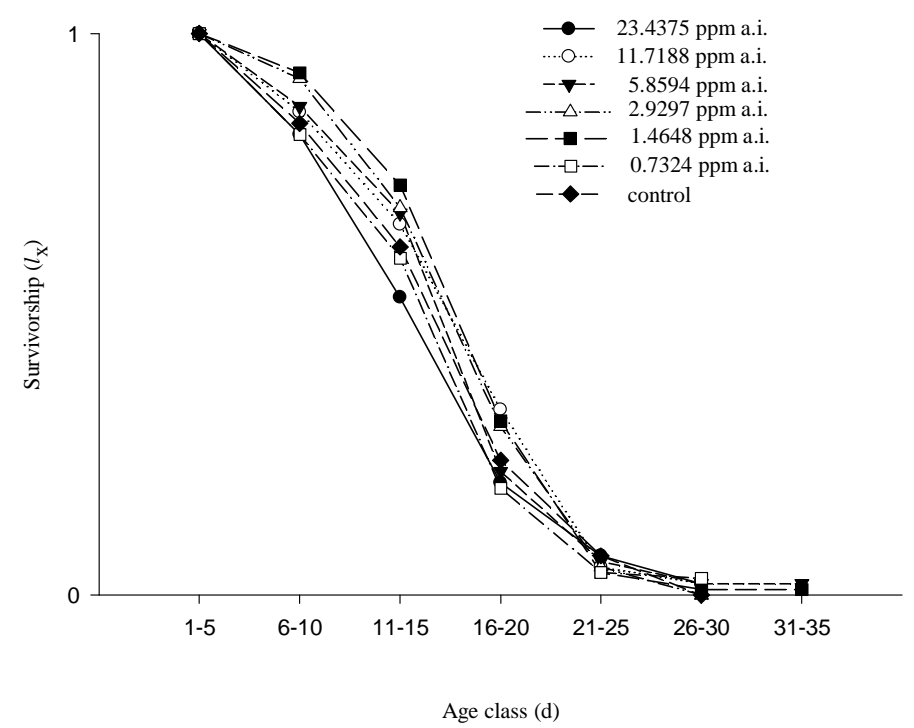

Figure 1 - Survival $\left(l_{x}\right)$ of Podisus nigrispinus (Heteroptera: Pentatomidae) adults treated as 2nd instar nymphs with sublethal doses of gammacyhalothrin. Observations of adults: $N=$ 96 at $23.4375 \mathrm{mg}$. litre $^{-1}, N=98$ at $11.7188 \mathrm{mg}$. litre $^{-1}, N=94$ at $5.8594 \mathrm{mg} \cdot$ litre $^{-1}, N=$ 101 at $2.9297 \mathrm{mg}$. litre $^{-1}, N=102$ at $1.4648 \mathrm{mg}$. litre $^{-1}, N=103$ at $0.7324 \mathrm{mg} \cdot$ litre $^{-1}$, and $N=106$ at the control. Age class $=$ five days. Survival $\left(l_{x}\right)$ is the survival rate from age class 0 to the beginning of age $\mathrm{x}$. 
Sublethal Effects on Body Weight, Longevity, and Reproduction

The sublethal doses of gammacyhalothrin did not affect the weight of $P$. nigrispinus females $(\mathrm{F}=$ $0.36 ; p>0.05)$ which was found for this predator and also for $P$. maculiventris after exposure to chemical compounds (Smaghee and Degheele, 1995).

P. nigrispinus females had greater longevity with 5.8594 mg.litre ${ }^{-1}$ (25.13 days) and 0.7324 mg.litre ${ }^{1}$ (27.79 days) than with $11.7188 \mathrm{mg} \cdot$ litre $^{-1}$ (10.38 days) of gammacyhalothrin and the control (23.65 days) $(\mathrm{F}=3.26 ; p=0.05)$ and to the other doses (Fig. 2). Pest species could have less longevity after exposure to sublethal doses of insecticides (Stewart and Philogene, 1983) but Tetranychus urticae Koch (Acari: Tetranychidae) had greater longevity after ingestion of imidacloprid (James and Price, 2002). Sublethal doses of permethrin did not affect the longevity of $P$. distinctus adults after topical exposition (Magalhães et al., 2002). This suggested that the hormesis phenomenon could occur even without an impact on other biotic characteristic.

\section{Fecundity and Reproduction}

The sublethal dose of 23.4375 mg.litre ${ }^{-1}$ of gammacyhalothrin decreased the oviposition period $(\mathrm{F}=6.66 ; p=0.05)$ of $P$. nigrispinus, except in the lowest dose $\left(0.7324 \mathrm{mg}\right.$.litre $\left.{ }^{-1}\right)$. The shortest preoviposition (2.25 days) $(\mathrm{F}=3.31 ; p=0.05)$ and postoviposition ( 0.25 days) $(\mathrm{F}=3.41 ; p=0.05)$ periods of this predator occurred when its females were exposed to $11.7188 \mathrm{mg}^{-l_{i t r e}{ }^{-1}}$ of this pyrethroid (Table 2).
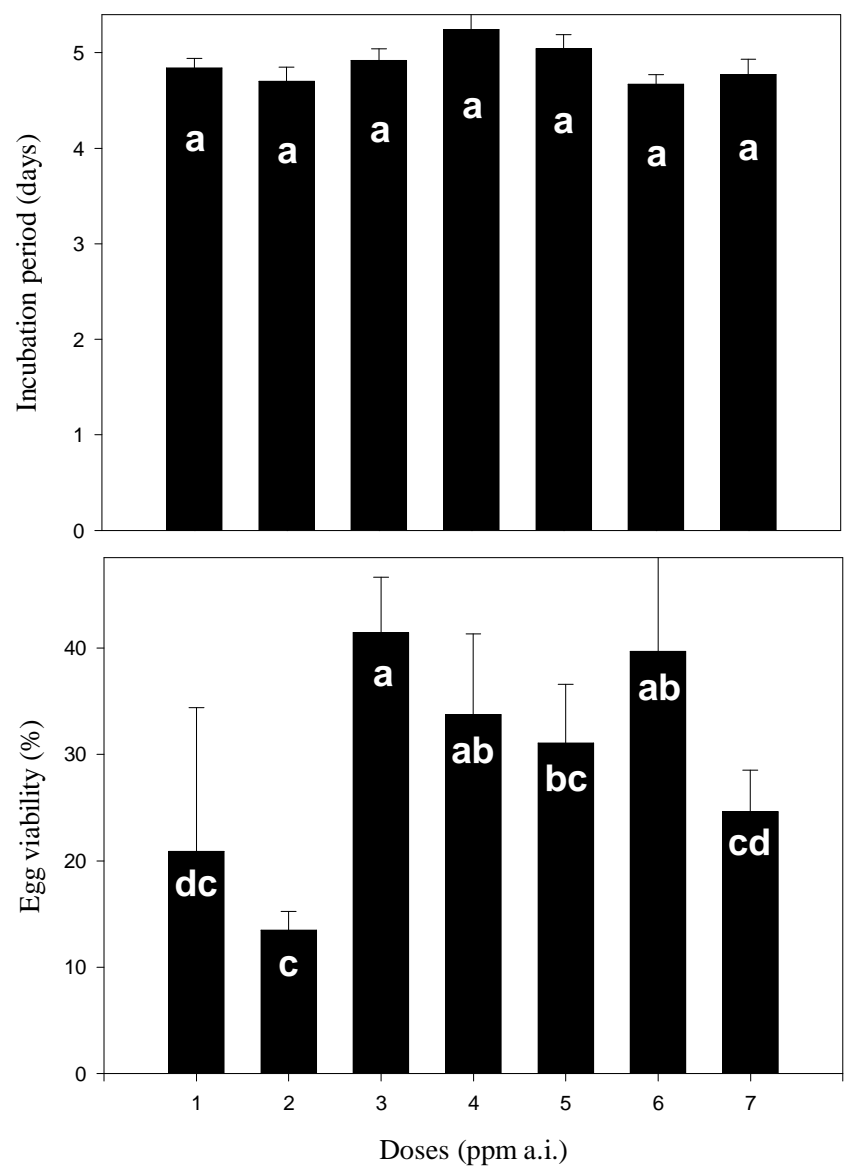

Figure 2 - Incubation period (days) and egg viability (\%) of Podisus nigrispinus (Heteroptera: Pentatomidae) submitted to sublethal concentrations of gammacyhalothrin (1= 23.4375 mg.litre $\mathrm{e}^{-1}, 2=11.7188 \mathrm{mg}$. litre $^{-1}, 3=5.8594 \mathrm{mg}$. litre $^{-1}, 4=2.9297 \mathrm{mg}$. litre $^{-1}, 5=$ $1.4648 \mathrm{mg}$. litre $^{-1}, 6=0.7324 \mathrm{mg} \cdot$ litre $\left.^{-1}\right)$, and only water $(7=$ dose-control $)$, at $26^{\circ} \mathrm{C}$, photoperiod of L:D 12:12 and relative humidity of $60 \pm 10 \%$. Student-Newman-Keul's test: for each variable, columns followed by the same letter are not different $(p=0.05)$. Error bars indicate the standard error. 
The highest doses of gammacyhalothrin reduced the preoviposition, oviposition and postoviposition periods of $P$. nigrispinus, which was also found for $S$. cincticeps with low dosages of permethrin $\left(5.74 \times 10^{-3}\right.$ and $\left.5.74 \times 10^{-2} \mathrm{ppb}\right)$ (Zanuncio et al., 2003). However, the pre-reproductive period of three coccinelid species were not affected by the exposure to copper sulfate fungicide (Michaud and Grant, 2003). The oviposition period of the $P$. maculiventris females was not affected by the sublethal doses of diflubenzuron and pyriproxyfen (De Clercq et al., 1995) found for other Pentatomidae predators (Zanuncio et al., 2003; Magalhães et al., 2002). Pesticides can have favorable effects on the biotic potential of arthropods (Ripper, 1956) even indirectly with low doses (Calabrese and Baldwin, 2000). The effects of insecticides on fecundity and reproduction of natural enemies depends on the species. O. $v$ nigrum females laid fewer eggs when treated with copper sulphate in the larvae stage (Michaud and Grant, 2003) and sublethal doses of azadiracthin reduced the number of fertile eggs of Chrysoperla carnea (Neuroptera: Chrysopidae). The number of eggs of $P$. maculiventris females per day was similar when they were exposed to sublethal doses of insecticides (De Clercq et al., 1995). However, G. pallens females that survived glyphosate and methomyl treatments laid more viable eggs (Yokoyama and Pritchard, 1984) and G. punctipes females laid more viable eggs after exposure to bentanzon and acifluorfen than those on untreated plants (Farlow and Pitre, 1983). This increase on egg deposition by $G$. punctipes after exposure to herbicides may represent hormesis (Luckey, 1968).

Table 2 - Reproductive parameters and longevity of Podisus nigrispinus (Heteroptera: Pentatomidae) females submitted to topical application of sublethal doses of gammacyhalothrin at $26^{\circ} \mathrm{C}$, relative humidity of $60+10 \%$, and photoperiod of L:D 12:12.

\begin{tabular}{|c|c|c|c|c|c|c|c|c|c|}
\hline \multirow{2}{*}{$\begin{array}{c}\text { Dose } \\
\left(\text { mg.litre }^{-1}\right) \\
\end{array}$} & \multicolumn{7}{|c|}{ Reproductive parameters (mean \pm standard error) ${ }^{1}$} & \multirow{2}{*}{$\begin{array}{c}\text { Longevity } \\
(\text { day })^{1} \\
\end{array}$} & \multirow{2}{*}{$\begin{array}{c}\text { Individua } \\
\text { (no) }\end{array}$} \\
\hline & $\begin{array}{c}\text { Preoviposition } \\
\text { (day) }\end{array}$ & $\begin{array}{c}\text { Oviposition } \\
\text { (day) }\end{array}$ & $\begin{array}{c}\text { Eggs/ } \\
\text { female (no) }\end{array}$ & $\begin{array}{c}\text { Eggs/clutch } \\
\text { (no) }\end{array}$ & $\begin{array}{c}\text { Clutch/ } \\
\text { female(no) }\end{array}$ & $\begin{array}{c}\text { Clutch } \\
\text { interval (day) }\end{array}$ & $\begin{array}{c}\text { Postoviposition } \\
\text { (day) }\end{array}$ & & \\
\hline 23.4375 & $4.29 \pm 0.77 \mathrm{ab}$ & $4.33 \pm 0.82 \mathrm{c}$ & $50.29 \pm 7.02 b$ & $6.88 \pm 2.71 \mathrm{a}$ & $4.08 \pm 2.49 \mathrm{c}$ & $2.25 \pm 0.60 \mathrm{c}$ & $2.00 \pm 0.35 \mathrm{ab}$ & $15.67 \pm 4.14 \mathrm{ab}$ & 96 \\
\hline 11.7188 & $2.25 \pm 0.85 b$ & $7.38 \pm 2.25 b c$ & $182.88 \pm 24.12 \mathrm{a}$ & $12.61 \pm 5.19 \mathrm{a}$ & $7.00 \pm 3.17 \mathrm{abc}$ & $3.13 \pm 1.11 b c$ & $0.25 \pm 0.25 b$ & $10.38 \pm 2.29 b$ & 98 \\
\hline 5.8594 & $3.38 \pm 0.77 \mathrm{ab}$ & $15.09 \pm 1.12 \mathrm{a}$ & $150.71 \pm 19.69 \mathrm{a}$ & $12.21 \pm 2.59 \mathrm{a}$ & $7.35 \pm 1.38 \mathrm{abc}$ & $7.75 \pm 1.61 \mathrm{ab}$ & $1.67 \pm 0.49 \mathrm{ab}$ & $25.13 \pm 2.31 \mathrm{a}$ & 94 \\
\hline 2.9297 & $5.81 \pm 0.92 \mathrm{a}$ & $9.69 \pm 1.92 \mathrm{ac}$ & $56.50 \pm 4.17 b$ & $13.90 \pm 3.06 \mathrm{a}$ & $4.83 \pm 0.92 \mathrm{bc}$ & $5.25 \pm 1.15 b c$ & $1.63 \pm 0.26 \mathrm{ab}$ & $18.00 \pm 2.22 \mathrm{ab}$ & 101 \\
\hline 1.4648 & $5.36 \pm 0.39 \mathrm{ab}$ & $11.86 \pm 2.38 \mathrm{ab}$ & $126.22 \pm 19.26 \mathrm{a}$ & $14.57 \pm 1.27 \mathrm{a}$ & $13.37 \pm 1.51 \mathrm{a}$ & $4.33 \pm 1.48 \mathrm{bc}$ & $2.01 \pm 0.32 \mathrm{ab}$ & $20.34 \pm 3.57 \mathrm{ab}$ & 102 \\
\hline 0.7324 & $5.06 \pm 0.78 \mathrm{ab}$ & $16.56 \pm 1.34 \mathrm{a}$ & $139.21 \pm 12.91 \mathrm{a}$ & $17.13 \pm 1.53 \mathrm{a}$ & $7.75 \pm 0.66 \mathrm{abc}$ & $9.94 \pm 1.30^{\mathrm{a}}$ & $4.00 \pm 1.40 \mathrm{a}$ & $27.79 \pm 2.80^{\mathrm{a}}$ & 103 \\
\hline Control & $6.30 \pm 0.90 \mathrm{a}$ & $17.40 \pm 2.67 \mathrm{a}$ & $162.60 \pm 20.37 \mathrm{a}$ & $6.99 \pm 2.38 \mathrm{a}$ & $12.35 \pm 1.41 \mathrm{ab}$ & $3.71 \pm 0.95 b c$ & $3.50 \pm 082 \mathrm{a}$ & $23.65 \pm 4.88 \mathrm{ab}$ & 106 \\
\hline $\mathrm{F}=$ & $3.31(p=0.05)$ & $6.66(\mathrm{p}=0.05)$ & $9.33(p=0.05)$ & $0.52(p>0.05)$ & $3.68(p=0.05)$ & $5.11(p=0.05)$ & $3.41(p=0.05)$ & $12.72(p=0.05)$ & ---- \\
\hline
\end{tabular}

${ }^{\mathrm{T}}$ Means followed by the same letter within each column are not different according to the Student-Newman-Keul's test ( $p=$ $0.05)$

P. nigrispinus females showed shortest clutch interval $(2.25$ days $)(\mathrm{F}=5.11 ; p=0.05)$ with the highest dose of $23.4375 \mathrm{mg}$. litre $^{-1}$ while that of 0.7324 mg.litre ${ }^{-1}$ of gammacyhalothrin increased the length of the clutch interval by more than a factor of two (9.94 days) compared to the control (3.71 days) (Table 2). However, the number of eggs per clutch $(\mathrm{F}=0.52 ; p>0.05)$, clutches per female $(\mathrm{F}=0.52 ; p>0.05)$ (Table 2), and the incubation period of $P$. nigrispinus eggs $(\mathrm{F}=2.20$; $p>0.05$ ) (Fig. 2) were not affected by the sublethal doses of gammacyhalothrin.
Females of $P$. nigrispinus had lower egg viability after exposure to the sublethal doses of 23.4375 and 11.7188 mg.litre ${ }^{-1}$ of gammacyhalotrin compared to the control (Fig. 2). The doses of 2.9297, 1.4648 and 0.7324 mg.litre $^{-1}$ of this insecticide increased the egg viability of this predator with highest value at $5.8594 \mathrm{mg} \cdot \mathrm{litre}^{-1}$ $(41 \%)(\mathrm{F}=10.89 ; p=0.05)$. The fall armyworm, Spodoptera frugiperda (Smith) (Lepidoptera: Noctuidae) showed higher egg viability with methomyl (Javid and All, 1984). Adults of the tobacco hornworm, M. sexta, showed greater 
reproductive potential when treated with an organosphorous pesticide (Stewart and Philogene, 1983). This behavior was also evidenced for mites (James and Price, 2002). On the other hand, the energy used can be sufficient for all the physiological processes of an insect even in the presence of a xenobiotic if the food supply is adequate. This is called hormesis which represents a strategy adopted by organisms for optimal allocation of energy (Calabrese and Baldwin, 2002).

The effect of a contaminant may not be easily predicted due to changes in the food sources and predator-prey dynamics (Boone and Semlitsch, 2003). The toxicity tests are difficult to compare due to variations in the methods used and factors such as high temperatures, sunlight, and rainfall that may reduce the effectiveness of an insecticide (Studebaker andd King, 2003). Chemical agents and other agents including other toxic substances can induce the hormesis (Calabrese and Baldwin, 2000). For this reason, differences in the effects of sub- lethal doses of chemicals on arthropods may be related to unconsidered factors (Calabrese and Baldwin, 2003).

\section{The Age-Dependent Fecundity Model}

The relationship between age-specific fecundity and age was described by a model composed of a linear function for the increase in fecundity at early ages combined with an exponential function for the subsequent decrease in egg laying at older ages. This relationship was described by $f(x)=\alpha x$ exp (- $\beta \mathrm{x})$ (Fig. 3). In the model $f(x)$ is the daily age-specific fecundity rate (eggs/female/day), $\mathrm{x}$ is the age in days (age class), and $\alpha$ and $\beta$ are constants. For age class 1 (1-5 days as adult), the model was fitted to the data by a non-linear least square technique (Sas Institute Inc., 2004), weighed by the number of females contributing to the means giving the curves in Figure 3. The parameters $\alpha( \pm$ SE) e $\beta( \pm$ SE), respectively, were estimated to be for the dose $1\left(23.4375 \mathrm{mg}\right.$. litre $\left.^{-1}\right)$ : $\alpha=25.9058 \pm 16.8295$ and $\beta=0.3301 \pm 0.1460$, dose 2 (11.7188 mg.litre $\left.{ }^{-1}\right): \alpha=37.2281 \pm 10.0815$ and $\beta=0.3498 \pm 0.0553$, dose 3 (5.8594 mg.litre $\left.{ }^{1}\right): \alpha=21.8516 \pm 8.5692$ and $\beta=0.2049 \pm 0.0634$, dose 4 (2.9297 mg.litre $\left.{ }^{-1}\right): \alpha=21.6907 \pm 8.9771$ and $\beta=0.2665 \pm 0.0791$, dose 5 (1.4648 mg.litre ${ }^{-}$ $\left.{ }^{1}\right): \alpha=23.4637 \pm 7.7215$ and $\beta=0.2520 \pm 0.0581$, dose $6\left(0.7324 \mathrm{mg} \cdot\right.$ litre $\left.^{-1}\right): \alpha=17.3428 \pm 4.0726$ and $\beta=0.1853 \pm 0.0285$, and the control $(1 \mu \mathrm{l}$ of distillated water): $\alpha=11.6798 \pm 3.4927$ and $\beta=$ $0.1559 \pm 0.0373$. The model explained that 68,83 , $84,83,87,87$, and $87 \%$ of the variation $\left(\mathrm{R}^{2}\right)$ of the fecundity of $P$. nigrispinus females submitted, respectively, to the doses of $23.4375,11.7188$, 5.8594, 2.9297, 1.4648, 0.7324, and $0.00 \mathrm{mg} . l i t r e^{-1}$ (control) of gammacyhalotrin was due to its age. The estimated model, describing the specific fecundity pattern of $P$. nigrispinus females as a function of its age, varied with the dose of the insecticide to which second instar nymphs were exposed.

Besides being numerically similar to the control, $P$. nigrispinus females laid more eggs with 11.7188 and $5.8594 \mathrm{mg}$. litre $^{-1}$ of gammacyhalotrin. Then, the capacity of $P$. nigrispinus to maintain its population growth under impact of a toxic agent represents a positive characteristic of an efficient natural enemy. 

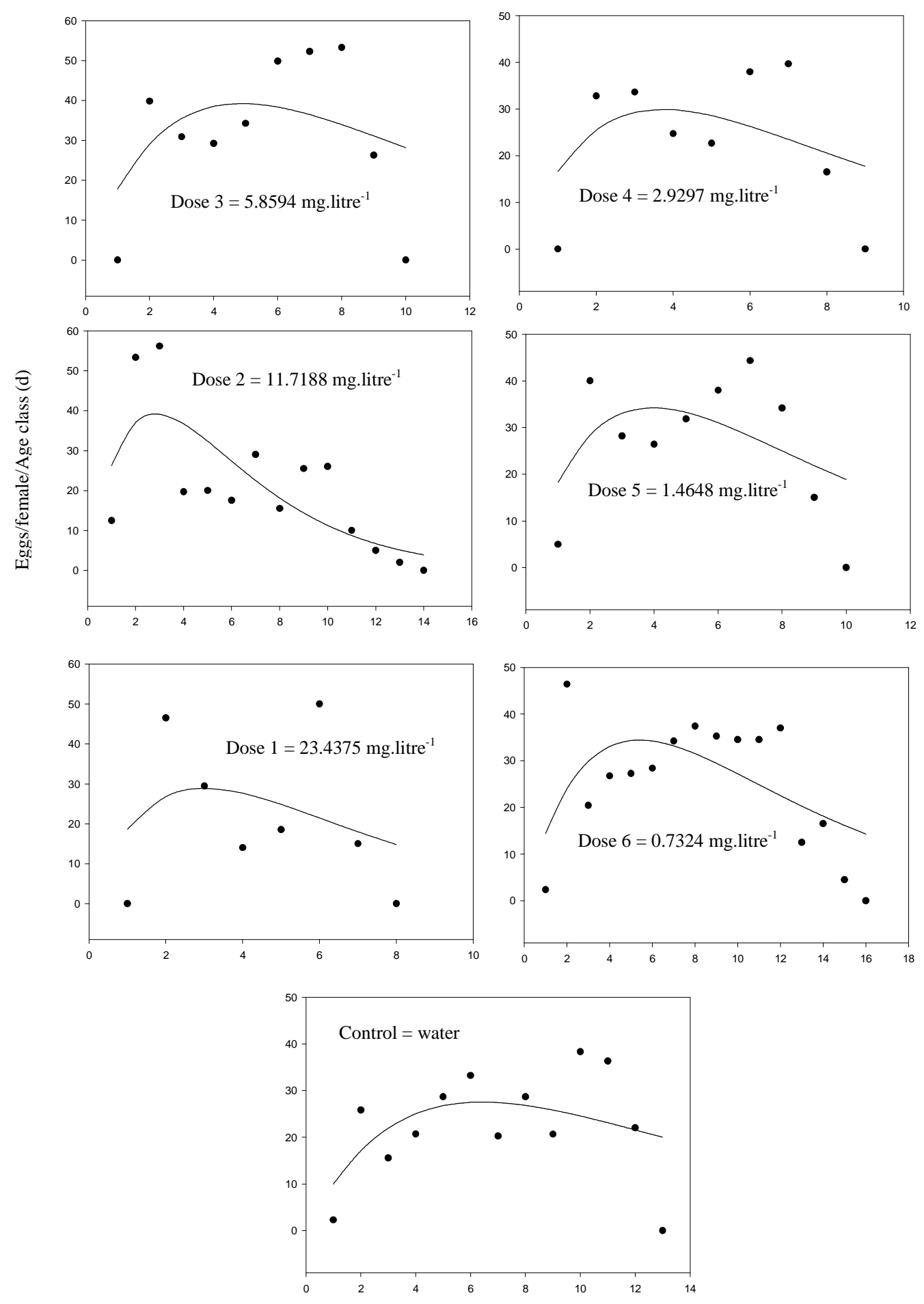

Age Class (5d)

Figure 3 - Observed (dots) and estimated (solid line model) values for the specific fecundity per age of Podisus nigrispinus (Heteroptera: Pentatomidae) females submitted to sublethal doses of gammacyhalothrin and on the control as function of female adult age. Age class representing females with one to five days of the adult stage (age class intervals = five days). 


\section{ACKNOWLEDGMENT}

The authors are indebted to "Conselho Nacional de Desenvolvimento Científico e Tecnológico (CNPq)" and "Fundação de Amparo à Pesquisa do Estado de Minas Gerais (FAPEMIG)" for financial support and fellowships.

\section{RESUMO}

Estudou-se o efeito estimulatório de baixas concentrações de gamacihalotrin sobre Podisus nigrispinus (Dallas)(Heteroptera: Pentatomidae). As doses de gamacihalotrin estudadas foram: $23,4375,11,7188,5,8594,2,9297,1,4648,0,7324$ mg.litro ${ }^{-1}$ e água (controle). Todas as doses estudadas de gamacihalotrin reduziram o período de desenvolvimento do $3^{\circ}, 4^{\circ}$ e $5^{\circ}$ ínstares de $P$. nigrispinus. A sobrevivência e a longevidade do predador foram mais altas quando foi exposto a baixas doses. O período de oviposição de $P$. nigrispinus reduziu á medida que foram aumentadas as doses de gamacihalotrin. A dose de 11,7188 mg.litro ${ }^{-1}$ de gamacihalotrin causou os mais curtos períodos de pré-oviposição e pósoviposição. $\mathrm{O}$ intervalo entre posturas aumentou com a dose de $0,7324 \mathrm{mg}$. litro $^{-1}$ de gamacihalotrin. A viabilidade de ovos não foi afetada pelo piretróide. O número de ovos por postura, posturas por fêmea, período de incubação e peso corpóreo de fêmea não foram afetados pelas doses testadas de gamacyhalotrin.

\section{REFERENCES}

Alford, A. R. and Holmes, J. A. (1986), Sublethal effects of Carbaryl, Aminocarb, Fenitrothion and Bacillus thuringiensis on the development and fecundity of the spruce budworm (Lepidoptera: Tortricidae). J. Econ. Entomol., 79, 31-34.

Boone, M. D. and Semlitsch, R. D. (2003), Interactions of bullfrog tadpole predators and an insecticide: predation release and facilitation. Oecologia 137, 610-616.

Boyd, M. L. and Boethel, D. J. (1998), Residual toxicity of selected insecticides to heteropteran predaceous species (Heteroptera: Lygaeidae, Nabidae, Pentatomidae) on soybean. Environ. Entomol., 27, 154-160.

Calabrese, E. J. and Baldwin, L. A. (2000). Chemical hormesis: its historical foundations as a biological hypothesis. Hum. Exp. Toxicol., 19, 2-31.
Calabrese, E. J. and Baldwin, L. A. (2002), Defining hormesis. Hum. Exp. Toxicol., 21, 91-97.

Calabrese, E. J. and Baldwin, L. A. (2003), Hormesis: the dose-response revolution. Annu. Rev. Pharmacol. Toxicol., 43, 175-197.

'De Clercq, P., De Cock, A., Tirry, L., Viñuela, E. and Degheele, D. (1995), Toxicity of diflubenzuron and pyriproxyfen to the predatory bug Podisus maculiventris. Entomol. Exp. App., 74,17-22.

De Cock, A., De Clercq, P., Tirry, L. and Degheele, D. (1996), Toxicity of diafenthiuron and imidacloprid to the predatory bug Podisus maculiventris (Heteroptera: Pentatomidae). Environ. Entomol., 25, 476-480.

Farlow, R. A. and Pitre, H. N (1983), Bioactivity of the postemergent herbicides acifluorfen and bentazon on Geocoris punctipes (Say)(Hemiptera: Lygaeidae). J. Econ. Entomol., 76, 200-203.

Fitt, G. P. (2000), An Australian approach to IPM in cotton: integrating new technologies to minimize insecticide dependence. C. Protec., 19, 793-800..

James, D. G. and Price, T. S. (2002), Fecundity in twospotted spider mite (Acari: Tetranychidae) is increased by direct and systemic exposure to imidacloprid. J. Econ. Entomol., 95, 729-732.

Javid, A. M. and All, J.N. (1984), Effects of methomyl on weight and development of fall armyworm (Lepidoptera: Noctuidae). J. Econ. Entomol., 77, 193196.

Jusselino Filho, P. (2002), Um pouco de algo perigoso pode ser bom? DSc. Thesis, Universidade Federal de Viçosa, Viçosa, MG, Brasil, 60 p.

Luckey, T. D. (1968), Insecticide hormoligosis. J. Econ. Entomol., 61, 7-12.

Magalhães, L. C., Guedes, R.N.C., Oliveira, E. E. and Tuelher, E. S. (2002), Desenvolvimento e reprodução do predador Podisus distinctus (Stal) (Heteroptera: Pentatomidae) frente a doses subletais de permetrina. N. Entomol., 31, 445-448.

Mccutcheon, G. S. and Durant, J. (1999), Survival of selected generalist predaceous insects exposed to insecticide residues on cotton. J.Cotton Sci., 3, 102108.

Medeiros, R. S., Ramalho, F.S., Zanuncio, J. C. and Serrão, J. E. (2003), Effect of temperature on life table parameters of Podisus nigrispinus (Heteroptera: Pentatomidae) fed with Alabama argillacea (Lepidoptera: Noctuidae) larvae. J. Appl. Entomol., 127, 209-213.

Michaud, J. P. and Grant, A. K. (2003), Sublethal effects of a copper sulfate fungicide on development and reproduction in thre e coccinellid species. $J$. Insect Sci., 3, 16-21.

Mohaghegh, J., De Clercq, P. and Tirry, L. (2000), Toxicity of selected insecticides to the Spined Soldier Bug Podisus maculiventris (Heteroptera: Pentatomidae). B. Sci. Technol., 10, 33-44. 
Perveen, F. (2000), Sublethal effects of chlorfluazuron on reproductivity and viability of Spodoptera litura (F.) (Lepidoptera: Noctuidae). J. Appl. Entomol., 124, 223-231.

Ramalho, F. S. (1994), Cotton pest management. part 4. A Brazilian perspective. Annu. Rev. Entomol., 39, 563-578.

Ripper, W. E. (1956), Effect of pesticides on balance of arthropod populations. Annu. Rev. Entomol., 1, 403438.

Ruberson, J. R., Herzog, G. A., Lambert, W. R. and Lewis, W.J. (1994), Management of beet armyworm (Lepidoptera: Noctuidae) in cotton: role of natural enemies. F. Entomol., 77, 440-453.

Sas Institute Inc. (2004), Sas user's guide: statistics. Cary: Sas Institute, 846 p.

Silva, E. N., Santos, T. M. and Ramalho, F. S. (1997), Consumo alimentar e crescimento do predador Supputius cincticeps (Stal) (Heteroptera: Pentatomidae) alimentando-se de lagartas de curuquerê-do-algodoeiro. Na. Soc. Entomol. Bras., 26, 349-357.

Smaghee, G. and Degheele, D. (1995), Selectivity of nonsteroidal ecdysteroid agonists RH 5849 and RH 5992 to nymphs and adults of predatory soldier bugs, Podisus nigrispinus and P. maculiventris (Hemiptera: Pentatomidae). J. Econ. Entomol., 88, 40-45.
Stewart, J. G. and Philogène, B. J. R. (1983), Sublethal effects of fenitrothion on the development of a parental generation of Manduca sexta. Entomol. Exp. Appl., 33, 315-319.

Studebaker, G. E. and King, T. J. (2003), Effects of insecticides on Orius insidiosus (Hemiptera: Anthocoridae), measured by field, greenhouse and Petri dish bioassays. Fl. Entomol., 86, 178-185.

Toft, S. and Jensen, A. P. (1998), No negative sublethal effects of two insecticides on prey capture and development of a spider. P. Sci., 52, 223-228.

Yokoyama, V.Y. and Pritchard, J. (1984), Effect of pesticides on mortality, fecundity, and egg viability of Geocoris pallens (Hemiptera: Lygaeidae). J. Econ. Entomol., 77, 876-879.

Yu, S. (1988), Selectivity of insecticides to the spinned soldier bug (Heteroptera: Pentatomidae) and its lepidopterous prey. J. Econ. Entomol., 81, 119-122.

Zanuncio, T. V., Serrão, J.E., Zanuncio, J. C. and Guedes, R. N. C. (2003), Permethrin-induced hormesis on the predator Supputius cincticeps (Stal) (Heteroptera: Pentatomidae). C. Protect., 22, 941947.
Received: March 27, 2007; Revised: November 23, 2007 ; Accepted: October 27, 2008. 